УДК 343.226

О.М. ІГНАТОВ, канд. юрид. наук, ст. наук. співр., Кримський юридичний інститут Одеського державного університету внутрішніх справ

\section{БІОЛОГІЧНІ ФАКТОРИ ДЕТЕРМІНАЦІї ЗЛОЧИННОї ПОВЕДІНКИ: ПОСТАНОВКА ПРОБЛЕМИ}

\section{Ключові слова: біологічні фактори, детермінація, злочинна поведінка}

Сьогодні злочинність являє собою порівняно самостійну, динамічну, імовірнісну соціальну систему, елементами якої є конкретні злочини, а також окремі види злочинів, об'єднані в однорідні групи. Відповідно й дослідження детермінації злочинності припускає застосування системного підходу дослідження всієї сукупності факторів, що детермінують злочинність як соціальне явище. При цьому, як цілком слушно зазначає Ю.М. Антонян, «криминология не должна с постоянством попугая твердить одно и то же: преступность социальна, она порождается обществом, она представляет собой разновидность социальных отклонений и т.д., недопустимо ограничивать этим свой научный поиск. Однако именно этим занято множество исследователей, не замечающих того, что они идут по пути, протоптанному много лет назад, и не желающих проводить эмпирические изыскания. Разве можно, используя лишь социологические результаты изучения преступности и ее причин, объяснить, например, серийные убийства, в том числе сексуальные, террористические акты, развратные действия в отношении несовершеннолетних, длительное ведение бродячего образа жизни и ряд других? Между тем социологические объяснения в криминологии продолжают доминировать даже тогда, когда это противоречит элементарному здравому смыслу» [1, с.3-16].

Проблема детермінації злочинної поведінки завжди привертала значну увагу науко- вців. Зокрема, цій проблемі присвячені праці: Г.А. Аванесова, Ю.М. Антоняна, В.В. Голіни, А.П. Закалюка, В.Н. Кудрявцева, Н.Ф. Кузнецової та ін. Однак, через складність питання, серед вчених на сьогодні не існує єдності поглядів на зазначену проблему, зокрема на роль біологічних факторів у детермінації злочинної поведінки.

Ученими-кримінологами давно і настійно ставиться питання про співвідношення біологічного і соціального в особистості злочинця. Дійсно, це питання $є$ принципово важливим при вивченні особистості злочинця і детермінації злочинної поведінки. Однак, чи розв'язане дане питання в такій його постановці?

Особистість - це система психічних процесів, станів і властивостей, які виникають, 3 одного боку, внаслідок соціалізації під впливом виховання і середовища, а з іншого боку у результаті перетворень уроджених внутрішніх умов організму, що управляють діяльністю людини, впливаючи на вибір нею різних способів поведінки [2]. 3 точки зору діалектико-матеріалістичного розуміння, особистість завжди виступає як конкретна людина, що характеризується соціально-психологічними і біологічними особливостями, що виступають у єдності і визначають програму і змістовну сторону іiї поведінки.

Як відзначив I.C. Ной, психологічний склад особистості похідний від діяльності людини і детермінований, насамперед, розвитком суспільних умов ії життя, однак індивідуальність, як неповторність кожної окремої людини, є, насамперед, факт біологічний [3, с.138]. Активно-діяльна природа людини завжди виступає в єдності суспільних і природних здатностей, вона проявляється в процесі реалізації людиною своїх біологічних i соціальних задатків і можливостей [4]. В «індивідуальній дії» людини можуть виявитися будь-які із наступних властивостей особистості: 1) соціально-психологічні особливості поведінки (у тому числі демографічні, культурні, соціальний і міжособистісний статус, ролі, стиль життя і спілкування); 2) спрямованість (потреби, мотиви, установка, життєві 
плани і концепції, ціннісні орієнтації, схильності, смаки); 3 ) психохарактерологічні якості (риси характеру, акцентовані властивості особистості); 4) психічні властивості і процеси (особливості інтелектуальної, емоційновольової сфери, сприйняття, увага, мова); 5) операціональні характеристики (звички, уміння, навички, знання); 6) біопсихічні властивості (статеві, вікові, морфологічні, темперамент, патологія, стан здоров'я); 7) особливості сексуальної сфери (сексуальна орієнтація, біологічні і соціальні фактори особистісної проблеми) [5]. Таким чином, людина народжується, формується і розвивається відповідно до соціально опосередкованих законів біології [6]. Відповідно до них реалізується й поведінка людини (ії вчинки), що характеризують іï як особистість.

Враховуючи викладене, на наш погляд, більш коректним, доречним і надзвичайно актуальним $є$ питання не про співвідношення біологічного і соціального в особистості злочинця, а про їхню взаємодію. 3 точки зору детермінації злочинної поведінки наука повинна відповістити на запитання: як взаємодіють біологічні і соціальні фактори в процесі детермінації поведінки людини i які негативні відхилення у цьому процесі можуть привести до вчинення злочину.

Метою даної статті є дослідження ролі біологічних факторів у детермінації злочинної поведінки. Її новизна полягає у встановлених основних напрямках дослідження біологічних факторів детермінації злочинної поведінки.

Як відзначив Д.К. Бєляєв, особистісні характеристики людини - у величезному ступені результат різноманітних умов виховання, соціальних умов життя, тих трудових i моральних настанов суспільства і конкретного оточення, у якому формується особистість. Однак відсутність жорсткої генетичної детермінованості зовнішніх проявів психіки людини в їхньому розвитку в індивідуума має лише зовнішній характер. Здатність сприймати норми соціального життя суспільства і реалізовувати їх в індивідуальної поведінки - генетично запрограмована влас- тивість, і вже в цьому полягає єдність соціального і біологічного в людині [7, с.36].

Особистість будь-якої людини формується їі діяльністю на підставі соціального і біологічного спадкування. Соціальне спадкування означає засвоєння індивідом створених попередніми поколіннями культурних, моральних і правових цінностей, традицій, звичаїв, а також інших правил поведінки. Біологічне спадкування здійснюється на підставі передачі народженому організму генетичної програми, за допомогою якої відбувається не тільки побудова тіла, але і біологічно обумовлені особливості психіки: темперамент, задатки, інтелект, тип нервової системи, а також спадкоємні хвороби, у тому числі і психічні. Особистість формується під впливом єдиного потоку біологічної і соціальної інформації, і в більшості випадків неможливо визначити головний провідний фактор, оскільки все взаємозалежно [8, с.25].

Отже, у людині концентрується й у певних рамках взаємодіє біологічна і соціальна інформація. В свою чергу, внутрішне відображення зовнішнього миру і відповідна реакція кожної особистості специфічна, як i увесь внутрішній світ людини, хоча він і соціально детермінований. Деякі сторони внутрішнього миру людини, іiї психологічного складу у більшій мері обумовлені біологічною природою.

Слід погодитися 3 Д.К. Бєляєвим, що «условия социальной жизни и воспитания действуют не на однородный и аморфный материал «усредненного» индивидуума, а на генетически дифференцированную во всех свойствах материю развивающегося и формирующегося человеческого мозга» [7, с.36].

Таким чином, основна проблема взаємодії біологічних і соціальних факторів у детермінації злочинної поведінки пов'язана 3 питанням, як і які біологічні фактори утрудняють процес їх «нормальної» взаємодії із соціальними. Тобто, необхідно з'ясувати, які біологічні особливості людини можуть негативно впливати на розвиток іï̈ як особистості і процес її соціалізації в цілому. 
Коротко проілюструємо дану проблему на прикладі психічних аномалій. Як зазначив I.М. Сєченов, на 999/1000 частин характер психіки (психічного змісту) людини залежить від виховання (у широкому сенсі слова) у більшості, але не у всіх випадках, та якщо людина народилася розумово неповноцінною, то це вже назавжди - розумною її виховати неможливо, оскільки властивість мозку від виховання не залежить [9, с.93-94].

Ученими встановлена наявність певного зв'язку деяких видів злочинів, насамперед насильницьких, 3 нервово-психічними детермінантами у вигляді аномалій психіки. Найбільш значною серед насильницьких злочинів із психічними аномаліями виявилася група осіб із залишковими явищами поразки центральної нервової системи. Для них характерні такі риси особистості, як підвищена збудливість, конфліктність, упертість, «сиюминутность» виникнення і задоволення антисуспільних потреб. Другою за поширеністю є група хронічних алкоголіків. На третьому місці - психопати. Четверта група олігофрени. Установлена також певна залежність між характером психічного захворювання і злочином [10, с.53]. Фахівці постійно звертають увагу на той факт, що саме серед насильницьких злочинців можна спостерігати значну питому вагу осіб 3 аномаліями психіки (від 70 до $90 \%$ серед вбивць; біля $80 \%$ серед гвалтівників та біля $70 \%$ серед осіб, що вчинили тілесні ушкодження) [11, c. $100-101 ; 12$, c.56;13].

Психічні аномалії можуть бути біологічного походження, або мати придбаний характер. Причинами виникнення психічних аномалій можуть бути наступні фактори (i їхні різні комбінації): 1) генетична спадковість, хромосомні порушення; 2) негативні фактори внутрішньоутробного розвитку плода: паління, уживання майбутньою матір'ю алкоголю, наркотиків, медичних препаратів, а також фактори, які провокують уроджену патологію; в) особливості оточуючого біологічного середовища (радіаційне та інше природне або техногенне забруднення тощо); 3) перенесені набуті (фізичні та психічні) захворювання та травми; 4) шкідливі звички та інші негативні практики: вживання алкоголю, наркотичних та токсичних речовин, перенапруга, стреси, неправильне харчування тощо.

На розвиток, перебіг і завершення передхворобних психічних розладів та психічних хвороб людини також можуть впливати як конституціонально-біологічні чинники: соматичні хвороби, екзогенні пошкодження головного мозку, психічні розлади в анамнезі, обтяженість спадковості психічними захворюваннями, психофізіологічні особливості людини (стан психофізіологічних якостей), так і соціально-психологічні (взаємовідносини в родині, робітничому колективі, матеріальний стан, соціальний стан, рівень настанови на роботу, специфічні умови діяльності, задоволеність соціально-економічними процесами в суспільстві, особистісні особливості людини) чинники [14].

Таким чином, враховуючи походження (причини виникнення та розвитку) психічних аномалій, не можна ігнорувати біологічну природу даного виду детермінант. Так, наприклад, як вже зазначалося, значна частка насильницьких злочинів вчиняється особами, які мають психічні аномалії у виді психопатії та олігофренії (олігофренів, до речі, як свідчать дослідження, серед всіх злочинців в 14-15 разів більше, ніж серед усього населення [11]). Зазначені психічні аномалії мають в абсолютній більшості випадків генетичне спадкове походження. Часто причини олігофренії криються в неправильному формуванні мозку, що може бути обумовлено спадковістю - неповноцінністю статевих клітин у батьків, які, як правило, також страждали на олігофренію. Однак ця неповноцінність в силу різних причин (інтоксикації, опромінення й ін.) може бути і у психічно здорових батьків. До ушкоджень головного мозку, що обумовлює олігофренію, можуть призводити різні шкідливі фактори, що діють на зародок або плід на різних стадіях вагітності, а також під час пологів або в післяпологовому періоді 
[15, с.24]. Етіологія психопатій також часто пов'язана з генетичними і спадкоємними факторами або з екзогенними шкідливостями, котрі діють на ранніх етапах онтогенезу [16, с.120].

Криміногенне значення психічних аномалій, на наш погляд, необхідно розглядати у двох аспектах. По-перше, злочинній поведінці активно сприяють зовсім не психічні аномалії як такі, а соціально-психологічні риси особистості, що формуються під їхнім впливом. Психічні аномалії істотно утрудняють опанування моральних, правових та інших соціальних норм, які регулюють відносини між людьми. Ці норми в їхніх очах знецінені, відштовхуються, як би не приймаються до уваги [17, с.17]. Однак, як слушно зазначає Ю.М. Антонян, цю обставину слід розглядати не ізольовано, а у контексті всіх зв'язків і відносин осіб з такими аномаліями. Справа у тому, що у соціальнопсихологічному плані вони, особливо при наявності сексуальних відхилень (при наявності психічних аномалій може порушуватися ієрархізованість мотивів сексуального акту, оскільки соціально обумовлені мотиви блокуються, в той же час, неможливість або складність задоволення потреб у сексуальній сфері, обтяженій сексуальними відхиленнями (особливо парафіліями та раптофіліями), сприяє виникненню та/або розвитку психічних аномалій), відрізняються відчуженістю від соціально-схвалюваних цінностей і малих соціальних груп, більшим, ніж здорові люди, вилученням 3 нормального спілкування, дезадаптацією у мікросередовищі. Відбувається це і тому, що вони мають суб' єктивно слабкі адаптивні можливості, і тому, що саме середовище їх часто виштовхує. Тому попереджувальний вплив на них інших людей значною мірою неефективний [17, с.17].

Так, наприклад, звертає на себе увагу той факт, що олігофренів серед гвалтівників удвічі більше, ніж серед вбивць, злодіїв, грабіжників і розбійників. Висока питома вага олігофренів серед гвалтівників пояснюється тим, що інтелектуальні розлади заважають їм установлювати контакти 3 жінками, у тому числі з метою сексуального зближення. Дефекти мови, обмежений запас слів і їхнє неправильне вживання і вимова, сповільненість дій, незграбність, одноманітність міміки і пантоміміки, «тупе» маскообразне обличчя, порушення будови черепа і т.д. у сполученні 3 неприємністю і неохайністю - все це 3 дитячих років утрудняє олігофренам взаємини 3 людьми, викликає в них озлоблення і замкнутість [18, с.131]. Таким чином, слід враховувати, що сприятливі соціальні умови взагалі можуть виявитися несприятливими для осіб 3 аномаліями психіки, що надає останнім криміногенні властивості.

По-друге, психічні аномалії знижують суб' єктивну можливість індивіда здійснювати саморегуляцію своєї поведінки, контроль за своїми діями; здатність приймати рішення на підставі адекватної оцінки ситуації, що склалася, $з$ урахування минулого досвіду та можливих наслідків; рівень критичного осмислення мотивів своїх вчинків; послабляють вольову складову людини, призначену протистояти антисоціальним усвідомлюваним бажанням і прагненням. Знижуючи вольові процеси, психічні аномалії послабляють дію контрольних механізмів і тим самим, найчастіше в сполученні з алкогольним сп'янінням (алкоголь у свою чергу сприяе розвитку психічних аномалій, що мають криміногенне значення, зокрема розвиток психопатій і психопатичних рис особистості), що збільшує ці емоційно-вольові порушення, сприяють реалізації імпульсивних, непродуманих протиправних насильницьких дій (у тому числі і вчиненню винятково жорстоких злочинів). Таким чином, психічні аномалії відображаються на інтенсивності переходу особи на злочинний шлях, однак нерідко і наслідки злочину носять відбиття психічних аномалій (невмотивованість злочину, афективність, сексуальні відхилення, особлива жорстокість і т.д.). Крім того, слід враховувати, що наявність аномалій психіки підвищує роль несвідомих явищ i процесів у злочинної поведінці, у силу чого, справжні мотиви такої поведінки усвідом- 
люються індивідом менше, ніж здоровою (без аномалій) людиною, тому керувати особі, яка має такі аномалії, своєю поведінкою складніше [19, с.52].

Таким чином, криміногенна роль психічних аномалій (як фактора біологічного походження) у детермінації кримінальної поведінки проявляється в тому, що вони можуть впливати не тільки на формування криміногенно-значимих негативних соціально-психологічних рис особистості, але і на сприйняття сприятливої (нейтральної) соціальної інформації і умов як несприятливих, що, враховуючи здатність психічних аномалій знижувати вольові процеси, послабляти дію контрольних механізмів, може в певній життєвій ситуації детермінувати злочинну поведінку індивіда, насамперед, пов'язану 3 застосуванням насильства.

Також яркою ілюстрацією даної «проблеми» біологічного походження, $\epsilon$ такий фактор детермінації злочинної поведінки, як сексуальні відхилення (сексуальні дисфункції; парафілії; порушення гендерної (статевої) ідентичності). Як зазначає 3. Старович, сексуальні відхилення (розлади, девіаціі), зокрема, парафілії, досить часто ведуть до скоєння кримінально караних діянь, бо немає збочення без активності, яка порушує статеві стандарти $[20$, с.47, 62]. Найбільш часто парафілії зустрічаються при різних психічних захворюваннях (шизофренії, психопатіях, олигофреніях тощо). У цих випадках структура парафілій відображає особливості психопатологічного грунту, на якому вона розвивається [21].

Незважаючи на те, що в процесі розвитку людина поступово навчається говорити, читати, писати, працювати, творити матеріальні і духовні цінності, вчиняти подвиги або провини, вона ніколи не перестає бути біологічною істотою $з$ усіма своїми інстинктами, почуттями, природними потребами, переживаннями і т.д. [22, с.59]. Пильна увага до соціологічного і соціально-психологічного вивчення особистості злочинця аж ніяк не означає заперечення того, що злочинна по- ведінка може мати позарольовий характер. Прикладами можуть бути злочини сексуальних психопатів, дії у вигляді ексгібіціонізму, феномен «тотальної агресивності» деяких насильницьких злочинців. В етіології таких злочинів очевидне місце, безперечно, належить індивідуально-психологічним властивостям особистості, у тому числі тим, що, видимо, мають природну основу. Нерозумно заперечувати той факт, що агресивний і сексуальний види поведінки закладені в людині біологічно [23, с.42-43].

У свою чергу, різноманіття проявів сексуальності людини як сукупності емоційних переживань і поведінкових актів обумовлено багатьма факторами - генетичними, гормональними, нервовими, психосоціальними, а також індивідуальними властивостями особистості [18, с.133]. Як зазначають фахівці, механізм розвитку сексуальних порушень під впливом саме біологічних факторів, завдяки дослідженням у сфері сексуальної фізіології, відомий краще, ніж механізми, обумовлені впливом факторів іншої природи. На формування свідомості і образа поведінки особистості у статевій сфері, в першу чергу, впливає статева конституція індивіда. Вона складається зі спадкових факторів у виді уродженої підвищеної збудливості, високій реактивності і толерантності або, навпаки, зниженої збудливості, легкої уразливості та передчасної зношуваності, безумовно, рефлекторних статевих центрів [24, с.87]. Біологічні фактори можуть впливати на різні ділянки статевої системи - рецепторну сферу (наприклад, ослаблення чутливості при деяких неврологічних захворюваннях), рефлекторну складову (наприклад, при ушкодженні нервових центрів ерекції і еякуляції або провідних нервових шляхів) тощо [20]. Причиною виникнення та розвитку сексуальних розладів можуть також бути деякі фізіологічні процеси в організмі людини, наприклад, сексуальні гормони не тільки регулюють процеси розвитку головного мозку, але і самі залежать від впливів середовища, перетворених головним мозком. 
Говорячи про біологічні особливості людини, які можуть негативно впливати на розвиток її особистості і процес іiі соціалізації в цілому i, як наслідок, детермінувати девіантну поведінку, необхідно також враховувати фізичні недоліки (аномаліі) людини.

Фізичні або психічні недоліки - це саме ті індивідуальні психофізичні особливості людини, які впливають на формування особистості, обмежують іï життєві інтереси і потреби. Уже само усвідомлення конкретних фізичних недоліків згубно позначається на психіці людини. Наявність каліцтв і інвалідності приводить до виникнення своєрідного характеру, звичок, поглядів, а іноді всієї поведінки. Такі люди погано пристосовані до соціальних умов [25, с.15].

Крім того, у силу тих або інших недоліків, що властиві людині, іiі фізичні і психічні властивості можуть не розвиватися, тому іiі здатності часом приймають виродливу форму, а сама особистість стає неповноцінною, дефективною, погано пристосованою до життя у певному соціальному середовищі. Люди, що страждають фізичними недоліками, відрізняються патологічними особливостями, які $\epsilon$ наслідком головним чином тих моральних, етичних і інших ускладнень, які виникають у взаємовідносинах подібних осіб з оточуючими, у їх фактичному суспільному положенні [26, с.47-48].

Наступна проблема стосується того, як i які біологічні фактори (крім зазначених вище психічних аномалій і сексуальних відхилень біологічного походження) можуть негативно впливати на реакцію людини соціальні фактори, що впливають на неї.

Так, тип нервової системи, наприклад, що полягає в основі темпераменту людини, властивий кожній людині від народження i впливає на образ іiі поведінки. Ще І.П. Павлов відзначав, що природжені властивості нервової системи поряд з вихованням і навчанням формують образ поведінки особистості.

Сутність людської поведінки, iii спрямованість та зміст мають, в першу чергу, соціальне походження і значення. В той же час ди- намічна сторона будь-якої поведінки, в тому числі злочинної, у широкому змісті слова, визначаються біологічними властивостями особи. Справа в тому, що властивості нервової системи, які безпосередньо не впливають ані на зміст психіки людини, ані на результативну сторону iї діяльності, виявляються, насамперед, в особливостях темпераменту, що додає своєрідного оформлення актам поведінки, і в певних умовах вони можуть мати вплив і на зміст певної діяльності [15, с.143]. Примітно, що серед розбійників близько $75 \%$ мають холеричний темперамент 3 більш високим рівнем тривожності, імпульсивності, агресивності [27, с.138].

Як відзначає Х.Г. Мелконян, сила відповідної реакції при помсті, ревнощах значною мірою залежить від психічного, нервового стану людини, іiï біологічної конституції, більшої або меншої збудливості, дратівливості і т.д. [22, с.55]. У свою чергу, до підвищення нервової збудливості чоловіків приводять кількісні порушення хромосомного набору (наприклад, при «YY-синдромі») [28].

Враховуючи вищевикладене, можна зробити висновок, що вплив біологічних факторів детермінації злочинної поведінки проявляється, насамперед, на психофізіологічному рівні. Вивчення даної проблеми припускає вивчення зв'язку і закономірностей впливу вроджених (ендогенних) - генетичних, гормональних і інших біологічних особливостей (відхилень), або придбаних (екзогенних) органічні поразки центральної нервової системи, особливості статевої конституції, алкоголізм і наркоманія і подібних біологічних особливостей на психофізіологічні особливості злочинців (особливості властивостей нервової системи, темпераменту тощо), що спричиняють порушення регуляції поведінки індивіда і сприяють його девіантним проявам.

Таким чином, до біологічних факторів детермінації злочинної поведінки, в першу чергу, слід віднести генетично спадкові конституціональні властивості людини (індивідуальні особливості та властивості, закріплені у генотипі особистості, що визначають 
особливості реакцій організму на вплив середовища), що визначаються особливостями морфологічної (хромосомної та тілесної) конституції людини та особливостями функціональних рис (біохімічної та фізіологічної конституції) та визначають особливості нейродинамічних (властивостей нервових процесів збудження та гальмування та їх різних комбінацій - сила-слабкість, врівноваженість, рухливість, динамічність, лабільність) та психодинамічних (темпераменту, сенситивності (сприйнятливості) тощо) властивостей особистості. Роль зазначених властивостей полягає, перш за все, в їх спроможності заважати нормальному формуванні особистості індивіда та його соціалізації.

Окрім генетичного спадкування на виникнення певних особливостей зазначених конституціональних властивостей людини можуть вплинути: 1) особливості оточуючого біологічного (природного) середовища (радіаційне та інше природне або техногенне забруднення тощо); 2) перенесені соціально набуті захворювання та травми; 3) шкідливі звички та інші негативні практики: вживання алкоголю, наркотичних та токсичних речовин, перенапруга, стреси, неправильне харчування тощо.

Окрему увагу при розгляді проблеми біологічних факторів детермінації злочинної поведінки слід приділити ролі факторів природного середовища, які кримінологи майже повністю ігнорують [29].

Людина є суспільною істотою, що належить соціальній цілісності. Особистість і іi свідомість є продуктом різноманітної діяльності, тобто освоєння індивідом миру соціальних відносин і перетворення його у внутрішні властивості індивідуальності. Властивості в цьому сенсі можуть бути 3 більшою або меншою силою пов'язані із психофізіологічною, біологічною природою людини, але завжди є результатом взаємодії індивіда 3 навколишнім середовищем. Тому вони можуть бути більш стійкішими стосовно впливу середовища або навпроти - податливими [30, c.128]. Як справедливо відзначає Ю.М. Анто- нян, у злочинної поведінці бере участь не тільки особистість, але і організм, тобто вся людина [1, с.16]. Людина, являючись єдністю двох взаємодіючих підструктур - біологічної і надбіологічної (психіки), як жива система, що являє собою нерозривну єдність біологічного та надбіологічного, може бути об'єктом найрізноманітніших факторів зовнішнього впливу.

Усі соціально-психологічні явища та процеси, які грають роль у детермінації злочинності, формуються та існують під впливом факторів природного середовища, тому зазначені фактори (перш за все, геліогеофізичного порядку) грають роль об'єктивної умови. При цьому, в залежності від ситуації вчинення окремого злочину, ці фактори можуть поряд 3 іншими формувати конкретну життєву ситуацію вчинення злочину.

3 іншого боку, фактори природного середовища можуть відігравати роль суб'єктивної передумови, що особливо яскраво можна простежити у випадках вчинення тяжких насильницьких злочинів особами 3 аномаліями психіки.

Зовнішній вплив природного середовища на людину являє собою енергетичний вплив на органи і тканини (їхні фізіологічні функціiі), тобто енергетичний вплив на обмін речовин та енергії організму 3 навколишнім середовищем і в середині самого організму, на рух, контрольно-регуляторну функцію, що здійснюється нервовою системою та на інші фізіологічні функції. При енергетичному впливі процес шкідливих змін у предметі впливу носить чисто матеріальний характер і пов'язаний 3 переносом фізичної енергії. 3 огляду на те, що одним з основних теоретичних принципів психології є визнання обумовленості психічних явищ матеріальною дійсністю, здійснення впливу на психіку людини можливо за допомогою різних факторів зовнішнього середовища. Оскільки численні інформаційні зв'язки, якими людина пов'язана 3 навколишнім середовищем здебільшого встановлюються на рівні підсвідомості людини, відповідні сигнали впливу природного 
середовища минаючи свідомість, безпосередньо впливають на підсвідомість, почуття.

Кажучи про роль природного середовища, перш за все, слід враховувати вплив геліогеофізичних факторів. При цьому треба враховувати, що сонячні і геофізичні варіації не змушують і не перешкоджають чинити протиправні діяння. Ці природні явища мобілізують, активізують або, навпаки, залежно від рівня і динаміки, примушують до зниження активності все, що пов'язане із психомоторною діяльністю людини. Іншими словами, геліогеофізична активність «не змушує робити щось конкретне, а що-небудь» [31, с.85].

Роль факторів природного середовища полягає, насамперед, у тому, що вони (насамперед, геліогеофізичні збурювання) впливають на здоров'я (у широкому розумінні) людини, у тому числі і психічне, стан якого у свою чергу є основою однієї із суб'єктивних складових умов конкретного злочину.

Так, наприклад, при впливі змін магнітного поля Землі (зміни якого залежать від сонячної активності) на стан здоров'я людини саме значення величини не відіграє головної ролі. Головне - сам факт його зміни. Діючі на організм, електромагнітні поля переносять в організм інформацію із зовнішнього середовища, а не енергію. У цьому їхня інформаційна роль [31, с.71]. Здоровий і хворий організми по-різному реагують на сонячні і геомагнітні бурі. При надходженні в організм сигналів про початок бурі, він відразу перебудовується, активізуючи резервні механізми пристосування, щоб вижити в нових, більш складних умовах. Зовнішні і внутрішні фактори діють на весь організм насамперед через кров (електромагнітну систему, чутливу до зовнішніх змін), через зміни в ній під їхнім впливом. Чим більш жалюгідний стан організму, тим раніше він відчуває дискомфорт, що наступив, і тим більш згубна його дія на нього. Ослаблений різними захворюваннями, у першу чергу нервово-психічними, наркотично залежний організм може бути доведений, принаймні, до стресового стану. Це в остаточному підсумку буде або може сприяти створенню сприятливих умов для вчинення злочину.

Як показують дослідження, існує залежність, наприклад, кількості ДТП від сонячної і геофізичної активності, при збільшенні якої нормальне функціонування організму, зокрема його центральної нервової системи, стає скрутним (збільшується час реакції, 3'являється загальмованість, повільність, погіршується кмітливість тощо) [31, с.80-81].

Знаходячись в сфері діяльності численних і різноманітних факторів періодичних процесів навколишнього середовища, у тому числі процесів життєдіяльності самого організму, людський індивідуум більше пристосований до певних циклів, до відносно стабільних в часі факторів зовнішнього середовища. Справа полягає тільки в тому, яка швидкість зміни досліджуваної характеристики. Різкі коливання в ході тих або інших елементів зовнішнього середовища можуть викликати в організмі той афективний стан, що звичайно служить певним грунтом для вчинення злочину [31, с.80-81].

Біоритмологами різних країн відмічені багатоденні періоди підйому та спаду різних психофізіологічних функцій організму людини. При цьому послідовність щоденних значень кожного показника (фізичного, емоційного, інтелектуального) більш-менш чітко повторюється через певні почти рівні відрізки часу. Існують багато результатів досліджень, присвячених змінам психофізіологічних показників у людини, біоритми якої знаходяться в різних фазах (позитивній, негативній та суміжному варіанті). Найбільша кількість серійних вбивств, наприклад, вчиняється коли всі три показники знаходяться у негативній фазі, найменша - у позитивній [32, c. 174-175].

Фактори природного середовища знаходять свій прояв у детермінації злочинної поведінки не лише при різких змінах магнітного поля Землі, викликаного геомагнітними факторами, але й при більш стабільних впливах (на кшталт, високій температурі повітря) при детермінації окремих найбільш 
тяжких насильницьких злочинів, що мають більш складну та потужну суб'єктивну складову детермінації.

У багатьох наукових джерелах, можна зустріти вказівку на залежність найбільшої частоти вчинення певних видів злочинів від пори року. Так, ще у працях Ч. Ломброзо можливо знайти вказівку на той факт, що максимальна кількість вбивств та згвалтувань у країнах Свропи (Англія, Франція, Італія) вчиняються у літні місяці [33, с.13-15]. Цікаво, що сучасні дослідження, проведені в нашій країні, показують ту ж саму залежність [34, с.8]. Інші дослідники вказують, що у літні місяці не лише різко збільшується кількість вбивств, а із загальної їх кількості саме на цей час приходиться найбільша кількість злочинів, вчинених у стані афекту. А співставлення статистичних даних різних країн світу переконливо підтверджує існування календарнотемпературного фактору детермінації насильницької злочинності [35, с.48-49].

Слід також враховувати i негативний вплив інших факторів природного середовища на здоров'я людини, зокрема на її психофізіологічний стан: радіаційне та інше природне або техногенне забруднення тощо. Так, серед біологічних передумов, що впливають на негативну поведінку людини, фахівці вказують, наприклад, на зміну хімічного складу навколишнього середовища, використання нових видів енергії, що призводить до різних психопатичних, алергічних, токсичних захворювань і слугує додатковим кримінальним чинником [36, с.75].

Враховуючи вищевикладене, можна зробити наступні висновки. Не вдаряючись ні в «вульгарне» «біологізаторство», ні в «соціологізаторство» (у неспроможності яких нас переконує розвиток людства) необхідно активізувати вивчення криміногенних детермінант обох видів i, що найбільш важливо, процесу і механізму їхньої взаємодії.

Вивчення біологічних факторів детермінації припускає, насамперед, необхідність дослідження зв'язку і закономірностей впливу на крайні девіантні прояви поведінки ін- дивіда: а) уроджених (ендогенних) - генетичних, гормональних i iнших біологічних особливостей (відхилень); б) придбаних (екзогенних) біологічних особливостей; в) факторів оточуючого біологічного (природного) середовища.

Слід враховувати, що лише комплексне використання наукових прийомів і методів пізнання, що застосовуються іншими науками, отримані у результаті їхнього застосування знань в області біології, психофізіології, психології, психіатрії, криміналістики, соціології і інших галузей наукового знання може бути відповідним фундаментом для побудови комплексного підходу до загальних і приватних проблем вивчення біологічних і інших факторів детермінації злочинної поведінки i, відповідно, протидії злочинності в цілому.

\section{ЛІТЕРАТУРА}

1. Антонян Ю. М. Понятие преступности, ее вечность / Ю. М. Антонян // Преступность и общество : сб. науч. трудов. - М. : ВНИИ МВД России, 2005. - С. 3-16.

2. Леонтьев А. Н. Деятельность. Сознание. Личность / А. Н. Леонтьев. - М. : Смысл, 2005. -352 c.

3. Ной И. С. Методологические проблемы советской криминологии / И. С. Ной. - Саратов : Изд-во Саратовск. ун-та, 1975. - 222 с.

4. Цареградов Г. И. Социокультурные функции современной медицины / Г. И. Цареградов, А. М. Изуткин // Вопросы философии. 1981. - № 9. - С. 41-49.

5. Бродченко О. И. Психолого-криминалистическое обеспечение раскрытия серийных сексуальных преступлений : метод. пособие / О. И. Бродченко, О. А. Логунова. М. : ВНИИ МВД России, 2004. - 118 с.

6. Базаров Р. А. Агрессия как биосоциальное явление / Р. А. Базаров // Проблемы борьбы с преступностью в регионах России / под. ред. А. В. Горбата : материалы науч.практ. конф., посвященной 10-летию НИЛ-9 ВНИИ МВД России. - М. : ВНИИ МВД Рос- 
сии, 1999. - С. 85-95.

7. Емельянов В. П. Преступность несовершеннолетних с психическими аномалиями / В. П. Емельянов ; под ред. И. С. Ноя. - Саратов : Изд-во Саратовск. ун-та, 1980. - 52 с.

8. Зелінський А. Ф. Детермінація злочину : навч. посіб. / А. Ф. Зелінський, Л. П. Оніка. Х. : УкрЮА, 1994. - 52 с.

9. Сеченов И. М. Рефлексы головного мозга / И. М. Сеченов. - М. : КомКнига, 2007. $128 \mathrm{c}$.

10. Антонян Ю. М. Преступное поведение лиц с психическими аномалиями и его профилактика / Ю. М. Антонян, М. В. Виноградов, Ц. А. Голумб // Вопросы борьбы с преступностью. - 1980. - Вып. 32. - С. 52-62.

11. Антонян Ю. М. Преступность и психические аномалии / Ю. М. Антонян, С. В. Бородин ; отв. ред. В. Н. Кудрявцев. М. : Наука, 1987. - 208 с.

12. Зелинский А. Ф. Криминальная психология. Научно-практическое издание / А. Ф. Зелинский. - К. : Юринком Интер, 1999. -240 c.

13. Голина В. В. Современные тенденции тяжкой насильственной преступности против личности и основные направления борьбы с нею / В. В. Голина // Проблеми боротьби з насильницькою злочинністю в Україні. - Х., 2001. - C. 54-60.

14. Долганов А. І. Система раннього прогнозування психічних розладів : автореф. дис. на здобуття наук. ступеня докт. мед. наук : спец. 14.01.16 / А. І. Долганов. - Х., 2000. - 36 с.

15. Ходимчук О. О. Насильницька злочинність осіб з психічними аномаліями та іï запобігання: дис. ... кандидата юрид. наук : 12.00.08 / Ходимчук О. О. - К., 2005.

16. Антонян Ю. М. Социальная среда и формирование личности преступника (неблагоприятные влияния на личность в микросреде) / Ю. М. Антонян. - М. : Академия МВД СССР, 1975. - 159 c.

17. Антонян Ю. М. Состояние и особенности сексуальной преступности : учеб. пособие / Ю. М. Антонян, М. И. Могачев. - М. : ВНИИ МВД России, 2004. - 66 с.
18. Антонян Ю. М. Особенности личности сексуального преступника // Преступность и общество : сб. науч. тр. / Ю. М. Антонян, М. И. Могачев. - М. : ВНИИ МВД России, 2005. - C. 127-136.

19. Антонян Ю. М. Преступное поведение и психические аномалии / Ю. М. Антонян, С. В. Бородин ; под ред. В. Н. Кудрявцева. М. : Спарк, 1998. - 215 с.

20. Старович 3. Судебная сексология / 3. Старович ; пер. с польск. - М. : Юрид. лит., 1991. $-336 \mathrm{c}$.

21. Ткаченко А. А. Механизмы аномального (противоправного) сексуального поведения при кратковременных расстройствах сознания / А. А. Ткаченко, Е. Ю. Яковлева // Преступное поведение (новые исследования) : сб. науч. тр. / под общ. ред. Ю. М. Антоняна. М. : ВНИИ МВД России, 2002. - С. 97-114.

22. Мелконян Х. Г. Проблема криминологического исследования мотивов и целей преступного поведения / Х. Г. Мелконян // Личность преступника и уголовная ответственность : межвуз. науч. сб. - Саратов : Издво Сарат. ун-та, 1981. - С. 53-63.

23. Резник Г. М. Личность преступника: правовое и криминологическое содержание / Г. М. Резник // Личность преступника и уголовная ответственность : межвуз. науч. сб. - Саратов : Изд-во Сарат. ун-та, 1981. - С. 29-44.

24. Затона Р. Е. Субъективные обстоятельства, способствующие совершению половых преступлений: криминолого-психологический анализ / Р. Е. Затона // Прикладная психология. - 2002. - № 3. - С. 84-93.

25. Щерба С. П. Расследование и судебное разбирательство по делам лиц, страдающих физическими или психическими недостатками / С. П. Щерба. - М., 1975. -144 с.

26. Сахаров А. Б. О тех, кто преступает закон / А. Б. Сахаров // Наука и жизнь. 1969. - № 5. - С. 47-48.

27. Батиргареєва В. С. Кримінологічна характеристика та попередження розбоїв, поєднаних з проникненням у житло: дис. ... кандидата юрид. наук : 12.00 .08 / Батиргареєва В. С. - Х., 2002. - 215 с. 
28. Малыхина Н. И. Актуальные вопросы развития криминалистического учения о личности преступника / Н. И. Малыхина // Opганизационно-правовые проблемы борьбы с преступностью в регионах России : сб. науч. тр. - М. : ВНИИ МВД России, 2005. C. 203-213.

29. Ігнатов О. М. Роль факторів природного середовища у детермінації злочинності / О. М. Ігнатов // Держава та регіони. Серія: Право. - 2009. - № 3. - С. 52-56.

30. Саркисов Г. С. Объект индивидуального профилактического воздействия в теории предупреждения преступности / Г. С. Саркисов ; отв. ред. Г. А. Аванесов. Ереван : Изд-во АН АрмССР, 1985. - 169 с.

31. Киселев С. Л. Теоретические основы гелиогеофизического прогнозирования преступности и чрезвычайных ситуаций: дис. ... доктора юрид. наук : 12.00.08 / Киселев С. Л. М., 2000. - 329 с.

32. Китаев Н. Н. О возможности вычисле- ния цикла нападений серийного убийцы по сексуальным мотивам / Н. Н. Китаев // Актуальні проблеми сучасної криміналістики : матеріали наук.-практ. конф. : у 2-х ч. Ч. 1. Сімферополь : Доля, 2002. - С. 174-175.

33. Ломброзо Ч. Преступный человек / Ч. Ломброзо ; пер. с итал. - М. : Эксмо; СПб. : Мидгард, 2005. - 880 с.

34. Губанова О. В. Кримінологічна характеристика та запобігання зґвалтуванню (на підставі матеріалів практики Автономної Республіки Крим) : автореф. дис. на здобуття наук. ступеня канд. юрид. наук : спец. 12.00.08 / О. В. Губанова - К., 2008. - 20 с.

35. Баронін А. С. Психологічний профіль вбивць : посібник з кримінальної психології та криміналістики / А. С. Баронін. - К. : ПАЛИВОДА, 2001. - $176 \mathrm{c.}$

36. Орбан-Лембрик Л. Залежність поведінки особистості від впливу проблемного соціуму / Л. Орбан-Лембрик // Психологія і суспільство. - 2004. - № 1. - С. 71-82.

Ігнатов О. М. Біологічні фактори детермінації злочинної поведінки: постановка проблеми / О. М. Ігнатов // Форум права. - 2010. - № 4. - С. 402-412 [Електронний ресурс]. - Режим достуny: http://www.nbuv.gov.ua/e-journals/FP/2010-4/10iomppp.pdf

Досліджено загальні питання взаємодії біологічних і соціальних факторів детермінації злочинної поведінки, встановлені основні напрямки дослідження біологічних факторів.

$$
* * *
$$

Игнатов А.Н. Биологические факторы детерминации преступного поведения: постановка проблемы

Рассмотрены общие вопросы взаимодействия биологических и социальных факторов детерминации преступного поведения, установлены основные направления исследования биологических факторов.

Ignatov A.N. The Biological Factors of Determinations of Criminal Behavior: Raising of Problem

The general questions of co-operation of biological and social factors of determinations of criminal behavior are considered, basis directions of research of biological factors are set. 